with pulmonary LCH and $\mathrm{PH}$ who quit smoking and received corticosteroids [10]. Whether antiproliferative therapy such as cladribine might affect $\mathrm{PH}$ in patients with pulmonary arterial wall involvement by Langerhan's cells is unknown.

In conclusion, these observations demonstrate that long-term improvement of $\mathrm{PH}$ may be obtained using bosentan in patients with pulmonary $\mathrm{LCH}$, further supporting the theory of pulmonary vasculopathy. Bosentan therapy may be considered in individual cases as a bridge to lung transplantation, which remains the therapy of choice in patients with pulmonary $\mathrm{LCH}$ and severe $\mathrm{PH}$.

\section{Kiakouama*, , V. Cottin ${ }^{*, \#, \S}$, B. Etienne-Mastroïanni*, C. Khouatra*, M. Humbert ${ }^{\sigma,+}$ and J.F. Cordier ${ }^{*, \#}$}

*Hospices civils de Lyon, Hôpital Louis Pradel, Service de Pneumologie-Centre de Référence des Maladies Pulmonaires Rares, "Université de Lyon, Université Lyon I, UCBL-INRAENVL-EPHE, UMR754, IFR128, Lyon, “Université Paris-Sud, Faculté de Médecine, Kremlin-Bicêtre, and ${ }^{+} \mathrm{AP}-\mathrm{HP}$, Centre National de Référence de l'Hypertension Pulmonaire Sévère, Service de Pneumologie et Réanimation Respiratoire, Hôpital Antoine Béclère, Clamart, France. ${ }^{\S}$ Both authors contributed equally.

Correspondence: V. Cottin, Dept of Respiratory MedicineReference Centre for Rare Lung Disorders, Louis Pradel Hospital, Lyon I University, 28 Avenue du Doyen Lepine, 69677 Lyon (Bron) cedex, France. E-mail: vincent.cottin@chu-lyon.fr

Statement of Interest: Statements of interest for V. Cottin, J-F. Cordier and M. Humbert can be found at www.erj. ersjournals.com $/ \mathrm{misc} /$ statements.dtl
Acknowledgements: The authors would like to thank Elements Communications Ltd (Kent, UK) for assistance with language editing.

\section{REFERENCES}

1 Lazor R, Etienne-Mastroïanni B, Khouatra C, et al. Progressive diffuse pulmonary Langerhans cell histiocytosis improved by cladribine chemotherapy. Thorax 2009; 64: 274-275.

2 Galiè N, Hoeper MM, Humbert M, et al. Guidelines for the diagnosis and treatment of pulmonary hypertension. Eur Respir J 2009; 34: 1219-1263.

3 Fartoukh M, Humbert M, Capron F, et al. Severe pulmonary hypertension in histiocytosis X. Am J Respir Crit Care Med 2000, 161: 216-223.

4 Dauriat G, Mal H, Thabut G, et al. Lung transplantation for pulmonary Langerhans' cell histiocytosis: a multicenter analysis. Transplantation 2006; 81: 746-750.

5 Chaowalit N, Pellikka PA, Decker PA, et al. Echocardiographic and clinical characteristics of pulmonary hypertension complicating pulmonary Langerhans cell histiocytosis. Mayo Clin Proc 2004; 79: 1269-1275.

6 Perros F, Montani D, Dorfmüller P, et al. Platelet-derived growth factor expression and function in idiopathic pulmonary arterial hypertension. Am J Respir Crit Care Med 2008; 178: 81-88.

7 Harari S, Simonneau G, De Juli E, et al. Prognostic value of pulmonary hypertension in patients with chronic interstitial lung disease referred for lung or heart-lung transplantation. J Heart Lung Transplant 1997; 16: 460-463.

8 Montani D, Price LC, Dorfmüller P, et al. Pulmonary venoocclusive disease. Eur Respir J 2009; 33: 189-200.

9 Behr J, Ryu JH. Pulmonary hypertension in interstitial lung disease. Eur Respir J 2008; 31: 1357-1367.

10 Benyounes B, Crestani B, Couvelard A, et al. Steroid-responsive pulmonary hypertension in a patient with Langerhans' cell granulomatosis (histiocytosis X). Chest 1996; 110: 284-286.

DOI: $10.1183 / 09031936.00004810$

\title{
Airway stent improves outcome in intubated oesophageal cancer patients
}

\section{To the Editors:}

Advanced, unresectable oesophageal cancer with airway invasion has a very poor prognosis. For tumours extending into the airway lumen, the primary goals of therapy are for the palliative relief of the malignant obstruction of the oesophageal lumen and central airway and to close the fistula between the oesophagus and central airway. Palliative options include mechanical core-out, dilatation, laser ablation, electrocautery, cryotherapy, photodynamic therapy and brachytherapy [1, 2]. However, satisfactory results may not be immediate or lasting. Endoscopic stenting is effective for airway stenosis from both extrinsic compression and direct tumour invasion, and has also been shown to be useful in the treatment of tracheo-oesophageal fistulas [3]. Among patients with obstruction of the trachea and main stem bronchi with tumour invasion, respiratory failure is one of the most severe complications. Due to advances in airway stents and insertion techniques, interventional bronchoscopic procedures have been reported to facilitate weaning from mechanical ventilation [4]. Moreover, covered self-expandable metallic stents have been used to seal off tracheo-oesophageal fistulas and to avoid aspiration symptoms [5]. However, little has been reported about the effect of stent implantation in respiratory failure patients with oesophageal cancer complicated with airway invasion.

As we previously reported, Ultraflex stent (Boston Scientific, Natick, MA, USA) placement in central airway obstruction, we retrospectively included 16 intubated patients with oesoageal cancer and central airway invasion after Ultraflex stenting in our intensive care unit (ICU) from 2001 to 2009 (table 1) [6]. The outcomes including ventilator weaning rate, ICU and overall survival were described. Most patients (11 out of $16(68.7 \%)$ ) were withdrawn from the ventilator and survived after airway Ultraflex stenting. Five patients were finally discharged from hospital and received further treatment including concurrent 
TABLE 1 Demographics and outcomes of patients who received airway Ultraflex stenting

\begin{tabular}{|c|c|c|c|c|c|c|c|c|c|c|c|}
\hline Case & $\begin{array}{l}\text { Age } \\
\text { yrs }\end{array}$ & Sex & $\begin{array}{l}\text { Invasion } \\
\text { site }\end{array}$ & Stent size ${ }^{\#}$ & Weaning & $\begin{array}{c}\text { ICU } \\
\text { outcome }\end{array}$ & $\begin{array}{c}\text { In- } \\
\text { hospital } \\
\text { outcome }\end{array}$ & $\begin{array}{l}\text { Hospital } \\
\text { days }\end{array}$ & $\begin{array}{l}\text { OS } \\
\text { days }\end{array}$ & Treatment & Complication \\
\hline 1 & 46 & Male & LT & $20 \times 8$ & - & M & M & 5 & 5 & None & Unknown \\
\hline 2 & 57 & Male & MT & $20 \times 8$ & + & S & S & 21 & 101 & RTO & Tumour ingrowth \\
\hline 3 & 56 & Male & LT & $20 \times 10$ & + & S & $S$ & 22 & 40 & CCRT & None \\
\hline 6 & 70 & Male & MT & $18 \times 8$ & + & S & M & 90 & 90 & None & TE fistula \\
\hline 7 & 71 & Male & MT & $18 \times 6$ & + & S & M & 82 & 82 & None & Secretion \\
\hline 8 & 55 & Male & LT & $16 \times 8$ & + & S & S & 8 & 45 & RTO & None \\
\hline 9 & 53 & Male & LT & $18 \times 6$ & + & S & S & 18 & 125 & CCRT & None \\
\hline 10 & 63 & Male & LT & $20 \times 6$ & - & M & M & 24 & 19 & None & Pneumothorax \\
\hline 11 & 73 & Male & LM & $18 \times 6$ & + & S & M & 43 & 37 & None & Migration \\
\hline 15 & 39 & Male & LM & $14 \times 4$ & - & $M$ & M & 47 & 31 & None & Secretion \\
\hline 16 & 61 & Male & LM & $14 \times 4$ & + & S & M & 23 & 16 & None & Unknown \\
\hline
\end{tabular}

ICU: intensive care unit; OS: overall survival; LT: lower trachea; MT: middle trachea; LM: left main bronchus; -: weaning failed; +: weaning succeeded; M: mortality;

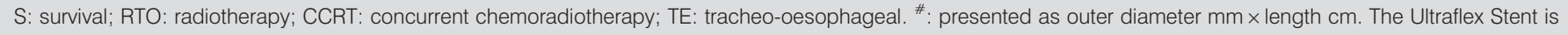
manufactured by Boston Scientific (Natick, MA, USA).

chemoradiotherapy (three out of $16(18.7 \%))$ or palliative radiotherapy (two out of $16(12.5 \%)$ ). The mean hospital stay survived durations were 36.1 (range 5-113) and 56.1 days (range 5-183). The ICU survival rate (10 out of $11(91 \%)$ versus zero out of five $(0 \%) ; \mathrm{p}<0.01)$ and overall survived duration (mean 75.3 days versus 13.8 days, $\mathrm{p}<0.01$ ) of patients who were successfully weaned were significantly better than those of patients who were not weaned from their ventilators.

All patients were in a critical condition, therefore general anaesthesia, rigid bronchoscopy and subsequent silicone stent implantation were not feasible. The alternative method of airway Ultraflex stenting, using flexible bronchoscopy without fluoroscopic guidance, provided these critical patients with alternative treatment to resolve their recurrent aspiration. After the stent was implanted successfully, we showed that some of these critical patients could be liberated from their ventilators and further discharged from the ICU and hospital. Thereafter, they could receive further treatment for oesophageal cancer including radiotherapy or concurrent chemoradiotherapy [7], and their overall chances of survival can improve. In conclusion, the current study describes an alternative method of stent implantation in mechanically ventilated patients with oesophageal cancer and central airway invasion. Despite these patients having a poor prognosis, this method may be lifesaving and may facilitate successful withdrawal from mechanical ventilation, hospitalisation in an environment with a lower level of care and may even extend their chances of survival. It may be difficult to enrol enough patients but a prospective study is warranted, investigating the added benefit of Ultraflex stents in respiratory failure patients due to oesophageal cancer with airway involvement.

\section{H-C. Lin, C-L. Chou, H-C. Chen and F-T. Chung}

Dept of Thoracic Medicine, Chang Gung Memorial Hospital, Chang Gung University, College of Medicine, Taipei, Taiwan.

Correspondence: F-T. Chung, Dept of Thoracic Medicine, Chang Gung Memorial Hospital, 199 Tun Hwa N. Rd., Taipei, Taiwan. E-mail: vikingchung@yahoo.com.tw

Statement of Interest: None declared.

\section{REFERENCES}

1 Cheng SL, Wang HC, Lee YC, et al. The role of bronchoscopic assessment in esophageal cancer - clinical and survival analysis in 153 patients. J Formos Med Assoc 2005; 104: 168-173.

2 Stephens KE Jr, Wood DE. Bronchoscopic management of central airway obstruction. J Thorac Cardiovasc Surg 2000; 119: 289-295.

3 Sihoe AD, Wan IY, Yim AP. Airway stenting for unresectable esophageal cancer. Surg Oncol 2004; 13: 17-25.

4 Colt HG, Harrell JH. Therapeutic rigid bronchoscopy allows level of care changes in patients with acute respiratory failure from central airways obstruction. Chest 1997; 112: 202-206.

$5 \mathrm{Li}$ YD, Li MH, Han XW, et al. Gastrotracheal and gastrobronchial fistulas: management with covered expandable metallic stents. J Vasc Interv Radiol 2006; 17: 1649-1656.

6 Chung FT, Lin SM, Chen HC, et al. Factors leading to tracheobronchial self-expandable metallic stent fracture. J Thorac Cardiovasc Surg 2008; 136: 1328-1335.

7 Koike R, Nishimura Y, Nakamatsu K, et al. Concurrent chemoradiotherapy for esophageal cancer with malignant fistula. Int $J$ Radiat Oncol Biol Phys 2008; 70: 1418-1422.

DOI: 10.1183/09031936.00193409 